\title{
ANTENATAL CARE QUALITY BY MIDWIVES AS A STUNTING PREVENTION EFFORT IN MALANG, EAST JAVA: A COMPARATIVE STUDY
}

\author{
Diadjeng Setya W, Miftahul Jannah, Rismaina Putri \\ Faculty of Medicine, Universitas Brawijaya, Malang, Indonesia
}

\begin{abstract}
Background: Fulfilment of nutrition in the first 1000 days of life greatly affects the development of a child's brain and body. If the nutritional intake is not fulfilled, the impact on children's development will be permanent, one of which is stunting. This study aimed to compare the quality of antenatal care (ANC) by midwives in the stunting locus and not the stunting locus village.

Subjects and Method: This was a comparative analytic with cross-sectional study conducted in stunting locus and not stunting locus village in Malang Regency from August-December 2019. A total of 84 midwives were enrolled in this study by purposive sampling. The data were collected by questionnaire. Data were analyzed using a multiple linear regression.

Results: Quality of ANC in stunting locus and not stunting locus village were not showing good results. The most dominant influence on the quality of ANC midwives in the stunting locus was the length of work of the midwives. Meanwhile, the most dominant influence on the quality of ANC midwives in non-stunting locus was the latest education.

Conclusion: Quality of ANC in stunting locus and not stunting locus village are not yet showing good results.
\end{abstract}

Keywords: stunting, quality, antenatal care, midwives

Correspondence:

Diadjeng Setya Wardani. Faculty of Medicine, Universitas Brawijaya. Jl. Veteran Malang, East Java, Indonesia.diadjeng_wardani@ub.ac.id.o85755540404

The $7^{\text {th }}$ International Conference on Public Health

Solo, Indonesia, November 18-19, 2020 | 186

https://doi.org/10.26911/the7thicph.03.06 